\title{
Using large dynamite shots to image the structure of the Moho from deep seismic reflection experiment between the Sichuan basin and Qinling orogen
}

\author{
Hongqiang Li • Rui Gao • Haiyan Wang • Wenhui Li • \\ Xiaosong Xiong
}

Received: 16 September 2015/ Accepted: 5 November 2016/Published online: 24 December 2016

(c) The Author(s) 2016. This article is published with open access at Springerlink.com

\begin{abstract}
The Qinling orogen was formed as a result of the collision between the North and South China blocks. The Qinling orogen represents the location at which the southern and northern parts of the Chinese mainland collided, and it's also the intersection of the Central China orogen and the north-south tectonic belt. There is evidence of strong deformation in this orogen, and it has had a long and complex geological history. We investigated the structure of the Moho in the southern Qinling orogen using large dynamite shot imaging techniques. By integrating the analysis of the single-shot and the move-out corrections profile, we determined the structure of the Moho beneath the northern Dabashan thrust belt and the southern Qinling orogen, including the mantle suture beneath Fenghuang mountain. The Moho is divided into two parts by the mantle suture zone beneath Fenghuang mountain: (1) from Ziyang to Hanyin, the north-dipping Moho is at about 45-55 km depth and the depth increases rapidly; and (2) from Hanyin to Ningshan, the south-dipping Moho is at about 40-45 km depth and shallows slowly. The mantle suture is located beneath Fenghuang mountain, and the Moho overlaps at this location: the shallower Moho is connected to the northern part of China, and the deeper Moho is connected to the southern part. This may indicate that the lithosphere in the Sichuan basin subducts to the Qinling block and that the subduction frontier reaches at least as far as Fenghuang mountain.
\end{abstract}

H. Li $(\varangle) \cdot$ R. Gao $\cdot$ H. Wang $\cdot$ W. Li $\cdot$ X. Xiong

Key Laboratory of Earthprobe and Geodynamics, MLR, Institute

of Geology, Chinese Academy of Geological Sciences,

Beijing 100037, China

e-mail: hongqiangli@126.com
Keywords Moho - Deep seismic reflection profiles · Large dynamite shots · Qinling Orogen, China

\section{Introduction}

The Qinling orogen is located in the center of the easttrending Central China orogen. The Central China orogen was formed when the northernmost part of the PaleoTethys ocean was sandwiched between the colliding North China and Yangtze blocks during the Mesozoic (Zhang et al. 2001; Dong et al. 2013; Li et al. 2015). As part of the Kunlun-Qilian-Qinling-Dabie orogen, it is considered to be formed through subduction, collision, and exhumation processes (Zhang and Liao 2003). The southern Qinling orogen is an important section of the Qinling orogen, and it can provide the key to resolve some of the issues related to its tectonic evolution. The Moho and the lower crust, the complex transition zone between the crust and the mantle, plays an important role on understanding the physics behind the dynamic processes acting in the Earth's interior.

It is proved that the deep seismic reflection profile can give higher-resolution images of the whole crust as well as the upper mantle compared with other geophysical approaches applied in imaging the Moho structure. Large dynamite shots can be used to determine the fine structure of the lower crust and Moho. For example, Klemperer et al. (1986) determined the structure of the Moho in Nevada, USA, using large dynamite shots. Kawamura et al. (2003) revealed the deep crustal structure of the eastern central tectonic line using two large dynamite shots. Stern et al. (2015) determined the structure of the Moho and the lithosphere-asthenosphere boundary beneath North Island, New Zealand, using large dynamite shots. 
In this paper, we develop new processing techniques and selected the appropriate parameters to image the structure of the Moho using five large dynamite shots in the southern Qinling orogen. The deep seismic reflection survey line starts from north of the Daba mountain thrust nappe zone and ends at the southern end of the Shangdan suture zone, passing through Ziyang, Hanyin, and Ningshan from south to north (Fig. 1).

\section{Tectonic setting}

The Qinling orogen is the western portion of the QinlingDabie orogenic belt, which was formed by the collision of the North China block and the Yangtze block in the Triassic (Fig. 1a) (Ames et al. 1996; Hacker et al. 1998). After the collision, the Qinling-Dabie orogenic belt was subjected to post-collisional intracontinental mountain-building, characterized by the intrusion of granitic plutons and large-scale extensional deformation (Peltzer et al. 1985; Xing et al. 2005; Zhang et al. 2004). The Qinling-Dabie belt is an important regional geological and climatic boundary in Central China. To the west of Qinling-Dabie

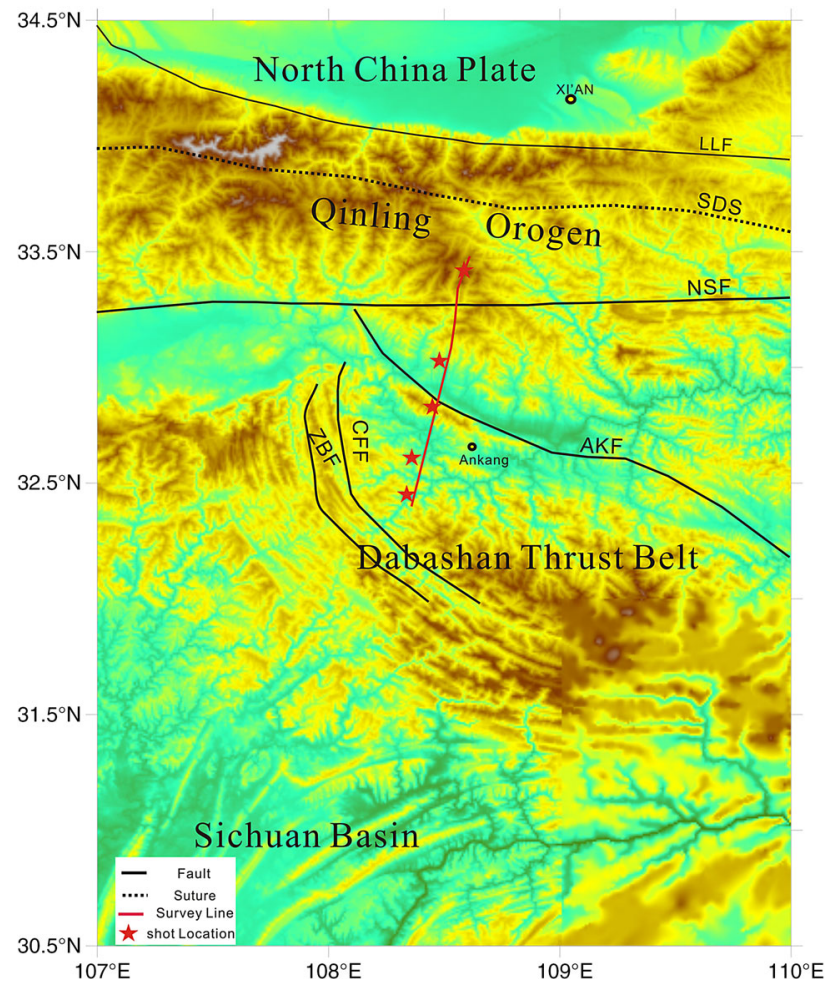

Fig. 1 Tectonic units and location of deep seismic reflection profile; red stars show the position of the five dynamite shots. $L L F$ Luanchuan fault; NSF Ningshan fault; $A K F$ Ankang fault; $Z B F$ Zhenba fault; and SDS Shangdan suture. (the location of southernmost shotpoint $\left(32.58^{\circ} \mathrm{N}, 108.35^{\circ} \mathrm{E}\right)$ and the northernmost $\left(33.46^{\circ} \mathrm{N}\right.$, $\left.108.57^{\circ} \mathrm{E}\right)$ belt, numerous active strike-slip and thrust faults form the northeastern margin of the Tibetan plateau and continue to the Kunlun and Qilian orogens (Burchfiel et al. 1991; Harkins et al. 2010; Yin et al. 2008; Liu et al. 2013). The Dabie orogen and the Sulu terrane lie the east of QinlingDabie belt (Hacker et al. 1998) and the north is the Ordos block, bounded by Cenozoic rift basins, which is tectonically stable with very little earthquake.

The geological framework and tectonic evolution of the Qinling orogen have been investigated extensively in the last few decades (Meng and Zhang 1999; Zhang et al. 1995a, b, 1996, 2001). The Qinling orogen is a multiple system orogenic belt with two mountain chains: the North Qinling range and the South Qinling range, which are separated by the strike-slip Shangdan suture (Fig. 1). The bedrock units outcropping in the Qinling orogen include Archean crystalline basement overlain by a series of Precambrian metamorphic rocks and Mesozoic-Paleozoic sedimentary strata, which were intruded by widespread granitoid plutons at 152-135 Ma (Zhang et al. 2001). Cenozoic sedimentary strata are preserved in the late Cretaceous-Cenozoic intermountain basins and rifted graben basins that resulted from normal and strike-slip faulting in the Qinling orogen.

\section{Acquisition and analysis of seismic data}

The seismic profile with the length of $140 \mathrm{~km}$ was deployed from March 2013 to September 2014, and the profile location is shown in Fig. 1. The characteristics of the Moho discontinuity depend strongly on the acquisition parameters, such as the amplitude and frequency content of the source signal and the geometry and deployment parameters of the recording system (e.g., the trace spacing and sample interval). These acquisition parameters control the resolution of the structure of the Moho. The images have a high dependence on the dynamic characteristics of the source signal (Carbonell et al. 2013).

To obtain high-resolution seismic images of the entire lithosphere, we used three different sizes of dynamite source (Table 1). The nominal $24 \mathrm{~kg}$ charge was placed in 25-m-deep boreholes at a spacing of $200 \mathrm{~m}$; additional shots of 96-120 kg were placed in one $35-\mathrm{m}$ or two $25-\mathrm{m}$ deep boreholes with a spacing of $1 \mathrm{~km}$. Charges of $500-2000 \mathrm{~kg}$ were fired every $30 \mathrm{~km}$ to acquire signals from deep in the lithosphere. The seismic data were acquired using a French Sercel $428 \mathrm{Xl}$ recorder and 24-bit digital seismic geophones. The geophones were placed at $40-\mathrm{m}$ spacings and had a dominant frequency of $10 \mathrm{~Hz}$. Table 1 lists all the data acquisition parameters. We used five large dynamite shots (charge $\geq 500 \mathrm{~kg}$ ) to image the structure of Moho. 
Table 1 Data acquisition parameters

\begin{tabular}{llll}
\hline Source & Dynamite & Large dynamite shot \\
\hline Charge size & $24 \mathrm{~kg}$ & $96-120 \mathrm{~kg}$ & $500-2000 \mathrm{~kg}$ \\
Shot interval & $200 \mathrm{~m}$ & $1000 \mathrm{~m}$ & $20-40 \mathrm{~km}$ \\
Shot depth & $25 \mathrm{~m}$ & $2 \times 25 \mathrm{~m}$ & $50-75 \mathrm{~m}$ \\
Spread & Symmetric split & Symmetric split & End-on \\
Far offset & $12 \mathrm{~km}$ & $12 \mathrm{~km}$ & $40 \mathrm{~km}$ \\
Sample rate & $2 \mathrm{~ms}$ & $2 \mathrm{~ms}$ & $4 \mathrm{~ms}$ \\
Record length & $30 \mathrm{~s}$ & $30 \mathrm{~s}$ & $60 \mathrm{~s}$ \\
Number of groups & 600 & 600 & $>1000$ \\
Group interval & $40 \mathrm{~m}$ & $40 \mathrm{~m}$ & $40 \mathrm{~m}$ \\
Geophone type & $\mathrm{Sm} 24-10 \mathrm{~Hz}$ & & \\
\hline
\end{tabular}

The quality of the large dynamite shot data was generally excellent, with signal returns above ambient noise levels, and there was a strong reflection from the lower crust and Moho (Fig. 2). The preliminary results indicate a highly reflective Moho. The dominant frequency was concentrated between 6 and $30 \mathrm{~Hz}$, suggesting that these large explosions, despite their low dominant frequency, may actually have a broader frequency than less powerful explosions ( $\mathrm{Li}$ et al. 2009; Jarchow et al. 1990). Reflections from different crustal depths could be detected from large explosive single-shot gathers. However, as a result of human activities, industrial noise, mining activities, and traffic along the profile, the quality of the data was inevitably affected; special attention was paid to this during data processing.

Compared with the data obtained using conventional average-sized and small amounts of dynamite (charge $<200 \mathrm{~kg}$ ), the data obtained using large dynamite explosions have stronger energy, a higher signal-to-noise ratio, a wider frequency band, and better continuity. The large

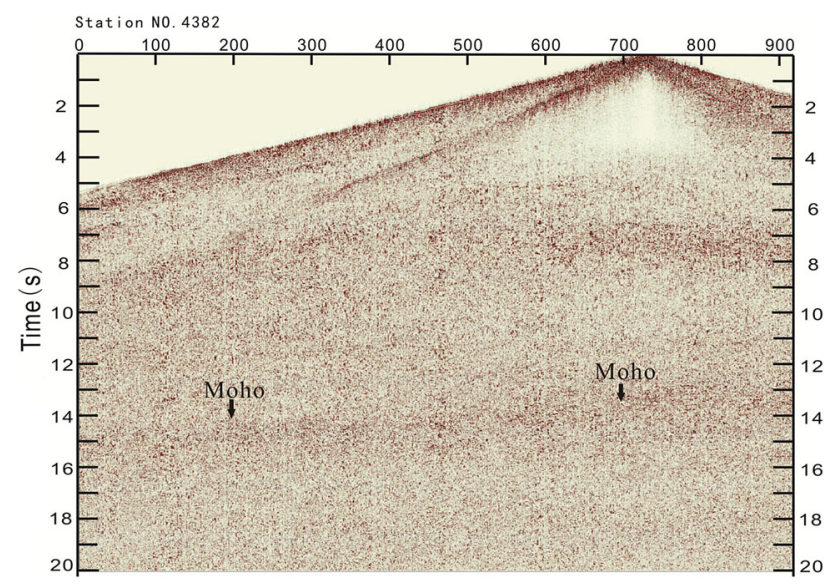

Fig. 2 Shot record for station number 4382 located at North Qinling; the acquisition parameters are given in Table 1 . The Moho reflection is easily identified dynamite shots could be used to discern and demarcate the reflective fabric of the lower crust and Moho. As the nearvertical incidence and reflection of the signal at the closest shotpoint are less affected by the seismic velocity, it may represent the lower crust and the Moho.

Current techniques for processing deep seismic reflection data typically only consider the similarities between the data obtained using large, average, and small explosions and ignores the differences in frequency, phase, and energy, which often leads to high signal-to-noise ratios. This means that reflections from the lower crust and Moho obtained using large dynamite shots are not correctly imaged in stacked or migrated sections. Developing the correct processes and selecting the correct parameters based on the characteristics of the data from the large dynamite shots are the key to imaging the lower crust and Moho. Many geophysicists have achieved good results in processing data from dynamite shots (e.g., Levander et al. 1994; Klemperer et al. 1986; Kawamura et al. 2003; Stern et al. 2015).

We selected five large dynamite shots (charge $>500 \mathrm{~kg}$ ) for processing. The structure of the Moho could be seen on the profiles from all five large dynamite shots, and the frequency range was $6-30 \mathrm{~Hz}$, consistent with the frequency of other reported deep seismic reflections from large dynamite shots (Stern et al. 2015; Jarchow et al. 1990; Steer et al. 1998). One large dynamite shot (Station No. 4382), located at the southern end of the Qinling Orogen, is shown in Fig. 2. This shot with $1500 \mathrm{~kg}$ of dynamite distributed in ten 50-m boreholes; the detailed acquisition parameters are listed in Table 1 . The energy of shot was relatively strong, and the reflection information was very rich, especially the two layers lying at 8 and $14 \mathrm{~s}$ from the shotpoint. The reflections at 12-14-s two-way travel time (TWTT) are the deepest high-amplitude, laterally extensive reflections in the raw data. The geometry of the Moho is curved; the TWTT of $14 \mathrm{~s}$ at the shotpoint gives a depth estimate of about $42 \mathrm{~km}$ with an average 
crustal velocity of $6 \mathrm{~km} / \mathrm{s}$ (Steer et al. 1998; Gao et al. 2013b; Guo et al. 2013) and can therefore be regarded as the depth of the Moho (Teng et al. 2014). The structure of the Moho is heterogeneous. With increasing receiving distance, the TWTT is increased gradually and reached $15 \mathrm{~s}(35 \mathrm{~km})$ at the furthest offset.

\section{Data processing}

By combining the advantages of the ProMAX and Omega systems, the seismic data were processed following a special procedure. The main processing steps included: Segd in; geometry definition; tomography static corrections; amplitude recovery; pre-stack noise attenuation; normal move-out correction; common middle points stacking; random noise attenuation; AGC; and filter. A detailed data processing flowchart is shown in Fig. 3, and the data processing parameters are summarized in Table 2 .

\section{Reflection characteristics of the Moho}

The processed seismic reflection section is shown in Fig. 4a. There are many large gaps in the section, some reaching to $10 \mathrm{~s}$ TWTT, as a result of a lack small offset data and the silent refraction and first arrival in the reflection data processing. The crust-mantle boundary is generally well defined at the bottom of the reflective crust (Cook et al. 2010). The Moho reflectors are distinguishable throughout the entire section and are characterized by strong sub-horizontal reflectors (Fig. 4a) appearing at 14.0-18.0-s TWTT. The Moho, the boundary/event between the crust and mantle, is clearly marked (Fig. 4b), The Moho depth is estimated to be $40-55 \mathrm{~km}$ with an average crustal velocity of $6.0 \mathrm{~km} / \mathrm{s}$ (Gao et al. 2013b; Guo et al. 2013). The shallowest Moho is located at $40 \mathrm{~km}$ in the northernmost part of the profile. Multiple Moho reflectors (45-55 km) appear below Fenghuang mountain, south of the Hanyin basin (Fig. 4b), and the deepest Moho reflectors were found at a depth of $55 \mathrm{~km}$. The deepest Moho is represented by overlapped reflectors in the vertical section (Fig. 4b), which is interpreted as the lithosphere in the Sichuan basin subducting to form the Qinling block; the subduction frontier reaches at least as far as Fenghuang mountain.

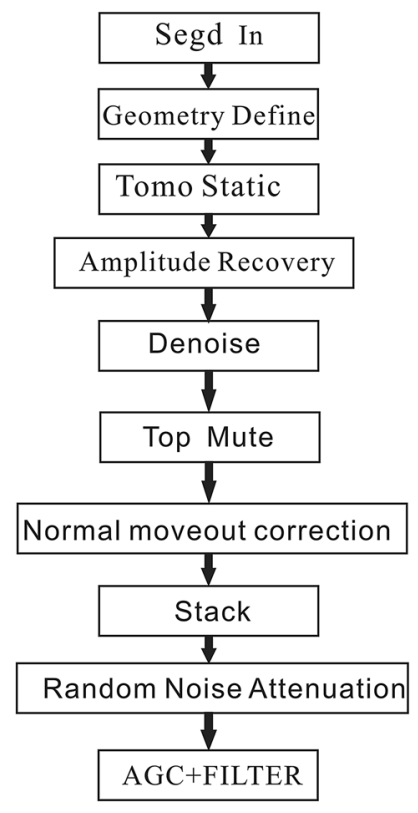

Fig. 3 Large dynamite shots data processing flow in deep seismic reflection

Table 2 Data process parameters

Data processing parameters (single-fold deep seismic reflection profile)

\begin{tabular}{ll}
\hline Flow & Parameters \\
Segd in & Length $30 \mathrm{~s}$, sample rate $4 \mathrm{~ms}$ \\
Geometry define & Crooked line CDP space $50 \mathrm{~m}$ \\
Tomostatic & Middle and small charge shot first arrival \\
& Offset 0-5 km, grid $25 \mathrm{~m} \times 100 \mathrm{~m}$ \\
& Datum elevation $2 \mathrm{~km}$ \\
& Replace velocity $4500 \mathrm{~m} / \mathrm{s}$ \\
& Geospread compensation t \\
Amplitude recovery & Trace balance window $5 \mathrm{~s}$ \\
& Linear wave 1800-3500, 290-320 m/s \\
Denoise & Industrial interference 50, 100 Hz \\
& Bad trace \\
& Removal refraction and direct wave \\
Top mute & Velocity from wide-angle data \\
NMO & NMO stretch 35\% \\
& \\
CDP sort & Traces $13 ;$ window 500 ms \\
RNA & Window length $2 \mathrm{~s}$ \\
AGC & $4-6-25-30 \mathrm{~Hz}$ \\
Bandpass filter & \\
\hline
\end{tabular}

$N M O$ normal moveout corrextion, RNA randon noise attenuation, $A G C$ auto gain control 


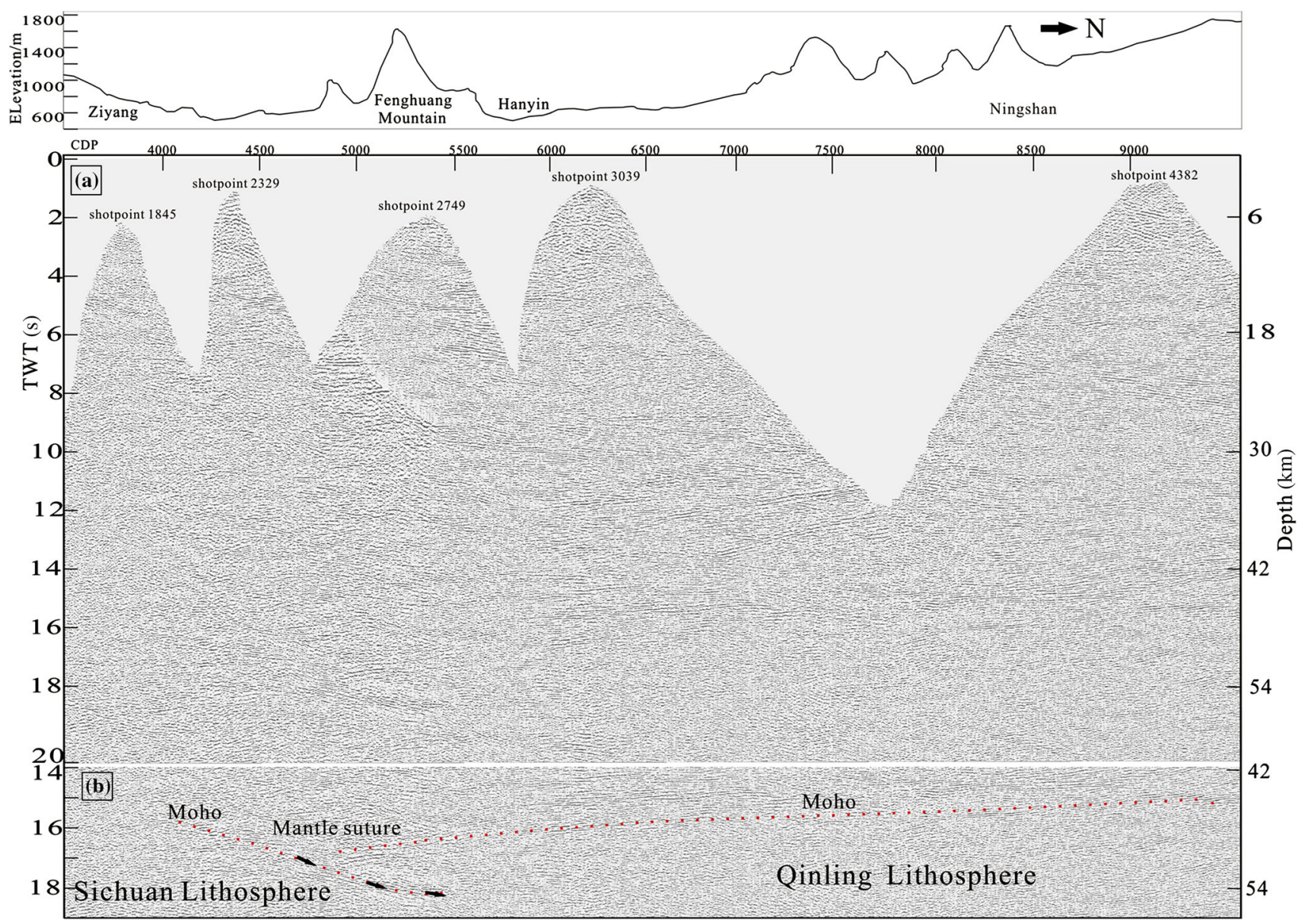

Fig. 4 a Profile in Qinling orogen by large dynamite shots from deep seismic reflection. b Moho structure beneath the southern Qinling orogen (red dotted line indicates the Moho structure). The approximate depth on the right side of the plot is estimated with an average crustal velocity of $6.0 \mathrm{~km} / \mathrm{s}$ (Gao et al. 2013a, b; Guo et al. 2013), and the final datum is $2 \mathrm{~km}$

\section{Conclusions}

We investigated the structure of the Moho using a large dynamite shot imaging technique. By integrating the analysis of the single-shot and the move-out corrections profile, we obtained the structure of the Moho beneath the northern Dabashan thrust belt and the southern Qinling orogen and identified the mantle suture beneath Fenghuang mountain.

These large dynamite shots reveal the fine structure of the Moho in the southern Qinling orogen. The Moho is divided into two parts by the mantle suture beneath Fenghuang mountain: (1) from Ziyang to Hanyin, the Moho is about at $45-55 \mathrm{~km}$ in depth and the depth increases rapidly; and (2) from Hanyin to Ningshan, the Moho with depth of about 40-45 km shallows slowly.

The mantle suture is located at Fenghuang mountain, and the Moho is overlapped at this location. The shallower Moho is connected to the northern area, and the deeper Moho is connected to the southern area. This may indicate that the lithosphere in the Sichuan basin subducts to the Qinling block and that the subduction frontier reaches at least as far as Fenghuang mountain.

Acknowledgements This study is funded by basic research funds of the Chinese Academy of Geological Sciences (J1628), the National Natural Science Foundation of China (Nos. 441590863 and 41430213) and the Ministry of Land and Resources of China (Nos. 201311159; SinoProbe-02-01).

Open Access This article is distributed under the terms of the Creative Commons Attribution 4.0 International License (http://crea tivecommons.org/licenses/by/4.0/), which permits unrestricted use, distribution, and reproduction in any medium, provided you give appropriate credit to the original author(s) and the source, provide a link to the Creative Commons license, and indicate if changes were made.

\section{References}

Ames L, Zhou G, Xiong B (1996) Geochronology and isotopic character of ultra-high pressure metamorphism with implications 
for collision of the Sino-Korean and Yangtze cratons, central China. Tectonics 15(2):472-489

Burchfiel BC, Zhang PZ, Wang YP, Zhang W, Song FM, Deng QD, Molnar P, Royden L (1991) Geology of Haiyuan fault zone, Ningxia-Hui Autonomous Region, China, and its relation to the evolution of the northeastern margin of the Tibetan Plateau. Tectonics 10(6): 1091-1110

Carbonell R, Levander A, Kind R (2013) The Moho discontinuity beneath the continental crust: An overview of seismic constrains. Tectonophysics. doi:10.1016/j.tecto.2013.08.037

Cook FA, White DJ, Jones AG, Eaton DWS, Hall J, Clowes RM (2010) How the crust meets the mantle: Lithoprobe perspectives on the Mohorovičić discontinuity and crust-mantle transition. Can J Earth Sci 47:315-351

Dong S, Gao R, Yin A, Guo T, Zhang Y, Hu J, Shi W, Li Q (2013) What drove continued continent-continent convergence after ocean closure? Insights from high-resolution seismic-reflection profiling across the Daba Shan in central China. Geology 41:671-674

Gao R, Chen C, Lu Z, Brown LD, Xiong X, Li W, Deng G (2013a) New constraints on crustal structure and Moho topography in Central Tibet revealed by SinoProbe deep seismic reflection profiling. Tectonophysics 610:160-170

Gao R, Wang H, Yin A, Dong S, Kuang Z (2013b) Tectonic development of the northeast Tibetan Plateau as constrained by high-resolution deep seismic-reflection data. Lithosphere 5(6):555-574

Guo XY, Gao R, Keller GR, Xu X, Wang HY, Li WH (2013) Crustalscale oblique uplift of the Longmen Shan block, eastern Tibetan Plateau. Earth Planet Sci Lett 379:72-80

Hacker BR, Ratschbacher L, Webb L, Ireland T, Walker D, Dong S (1998) U/Pb zircon ages constrain the architecture of the ultrahigh-pressure Qinling-Dabie Orogen, China. Earth Planet Sci Lett 161:215-230

Harkins N, Kirby E, Shi X, Wang E, Burbank D, Chun F (2010) Millennial slip rates along the eastern Kunlun fault: implications for the dynamics of intracontinental deformation in Asia. Lithosphere 2(4):247-266

Jarchow CM, Goodwin EB, Catching RD (1990) Are large explosive sources applicable to resource exploration? Lead Edge $9(1): 12-17$

Kawamura T, Onishi M, Kurashimo E, Ikawa T, Ito T (2003) Deep seismic reflection experiment using a dense receiver and sparse shot technique for imaging the deep structure of the Median Tectonic Line (MTL) in east Shikoku, Japan. Earth Planet Space 55:549-557

Klemperer SL, Hauge TA, Hauser EC, Oliver JE, Potter CJ (1986) The Moho in the northern Basin and Range province, Nevada, along the COCORP $400 \mathrm{~N}$ seismic reflection transect. Geol Soc Am Bull 97(5):603-618

Levander A, Fuis GS, Wissinger ES, Lutter WJ, Oldow JS, Moore TE (1994) Seismic images of the Brooks Range fold and thrust belt, Arctic Alaska, from an integrated seismic reflection/refraction experiment. Tectonophysics 232:13-30
Li QS, Gao R, Wang HY, Zhang JS, Lu ZW, Li PW, Guan Y, He RZ (2009) $200-\mathrm{kg}$ large explosive detonation facing 50-km thick crust beneath west Qinling, northeastern Tibetan plateau. Earthq Sci 22:389-393

Li Y, Yang J, Dilek Y, Zhang J, Pe X, Che S, Xu X, Li J (2015) Crustal architecture of the Shangdan suture zone in the early Paleozoic Qinling orogenic belt, China: record of subduction initiation and backarc basin development. Gondwana Res 27:733-744

Liu J, Zhang P, Lease R, Zheng D, Wan J, Wang W, Zhang H (2013) Eocene onset and late Miocene acceleration of Cenozoic intracontinental extension in the North Qinling range-Weihe graben: insights from apatite fission track thermochronology. Tectonophysics 584:281-296

Meng QR, Zhang GW (1999) Timing of collision of the North and South China blocks: Controversy and reconciliation. Geology 27:123

Peltzer G, Tapponnier P, Zhang Z, Xu ZQ (1985) Neogene and quaternary faulting along the Qinling Shan. Nature 317:500-505

Steer DN, Brown LD, Echtler HP, Brown DL, Berzin R (1998) Deep structure of the continental lithosphere in an unextended orogen: an explosive-source seismic reflection profile in the Urals, Urals Seismic Experiment and Integrated Studies (URSEIS 1995). Tectonics 17:143-157

Stern TA, Henrys SA, Okaya D, Louie JN, Savage MK, Lamb S, Sato $\mathrm{H}$, Sutherland R, Iwasaki T (2015) A seismic reflection image for the base of a tectonic plate. Nature 518:85-88

Teng JW, Li SL, Zhang YQ (2014) Fine velocity structures and deep processes in crust and mantle of the Qinling orogenic belt and the adjacent North and Yangtze craton. Chin J Geophys 57(10):3154-3175 (in Chinese with Einlish abstract)

Xing ZY, Zhao B, Tu M (2005) The formation of the Fenwei rift Valley. Earth Sci Front 12(2):247-262

Yin A, Dang Y, Zhang M, Chen X, McRivette MW (2008) Cenozoic tectonic evolution of the Qaidam Basin and its surrounding regions: part 3. Structural geology, sedimentation, and regional tectonic reconstruction. Geol Soc Am Bull 120:847-876

Zhang Y, Liao C (2003) Late Mesozoic Cenozoic tectonic regime switching and Ordos Basin reconstruction. Chin Geol 33:28-40 (in Chinese with English abstract)

Zhang G, Meng Q, Lai S (1995a) Tectonics and structure of Qinling orogenic belt. Sci China 38(11):1379-1394 (in Chinese with English abstract)

Zhang G, Xiang L, Meng Q (1995b) The Qinling orogenic and intracontinental orogenic mechanism. Episodes 18(1-2):36-39

Zhang GW, Meng QR, Yu Z, Sun Y, Zhou D, Guo AL (1996) Orogenic processes and dynamics of the Qinling. Science China Earth Sci 39(3):225-234 (in Chinese with English abstract)

Zhang GW, Zhang B, Yuan X, Xiao QH (2001) Qinling orogenic belt and continental crust, Geodynamics. Science Press, Beijing (in Chinese)

Zhang G, Dong Y, Lai S (2004) Mianlue tectonic zone and Mianlue suture zone on southern margin of Qinling-Dabie orogenic belt. Sci China 47(4):300-316 (in Chinese with English abstract) 